\title{
Congregation Perception towards the Roles and Responsibilities of the Mosque Imams in Terengganu Malaysia
}

\author{
Dr. Rohaizan bin Baru (Corresponding author) \\ Faculty of Islamic Contemporary Studies, Universiti Sultan Zainal Abidin, Gong Badak Campus \\ Gong Badak, 21300, KualaTerengganu, Terengganu, Malaysia \\ Tel: 60-19-914-7438Ｅ-mail: rohaizan@unisza.edu.my
}

Fauzilah Binti Salleh

Faculty of Business Management and Accountancy, Universiti Sultan Zainal Abidin, Gong Badak Campus

Gong Badak, 21300, KualaTerengganu, Terengganu, Malaysia

E-mail: fauzilah@unisza.edu.my

\author{
Jamaluddin Hashim, Wan Fajrul Hisham Wan Abdullah \& Rosmalizawati Ab Rashid \\ Faculty of Islamic Contemporary Studies, Universiti Sultan Zainal Abidin, Gong Badak Campus \\ Gong Badak, 21300, KualaTerengganu, Terengganu, Malaysia \\ E-mail: jamalluddin@unisza.edu.my,wfajrul@unisza.edu.my,rosma@unisza.edu.my
}

Received: May 20, $2011 \quad$ Accepted: July 5, $2011 \quad$ Published: December 1, 2011

doi:10.5539/ass.v7n12p258 URL: http://dx.doi.org/10.5539/ass.v7n12p258

\begin{abstract}
This paper attempted to review the congregants' perception of the roles and responsibilities of Imam which rely on three dimensions: the official duties, the administration of the mosque and the community services. A comprehensive survey in the entire state of Terengganu has been outlined with several major goals; to identify the roles and responsibilities of an Imam, to analyses the perception of the roles and responsibilities of the Imam from the aspect of official duties, the administration of mosques, and also the community services.
\end{abstract}

Keywords: Congregants' perception, Imam, Terengganu

\section{Introduction}

In this paper, the researches questioned about the real roles and responsibilities of an Imam that being appointed by the government and analyzing what are the congregants' perceptions of the role of the Imam from the aspect of official duties, the administration of the mosque and community services. With that, the researchers able to gather an information about the congregants' perception towards their religious leaders especially as Imam in the community.

\section{Theoretical Framework}

\subsection{Definition of the Mosque}

Mosque is the centre of the human capital development either from the aspect of spiritual, moral or social life. It becomes a focal point in strengthening the Islamic brotherhood, building the mutual understanding, developing the unity and harmony, the justice and the grandeur of Islam (Ajmain, 2004). In another word, the mosque is an institution that symbolizes the heart of the Islamic society development for the world and hereafter (Abdullah, Mat, 2003). The numbers of mosques in Malaysia are more than 5,300 (Roslan, 2004) and in the state of Terengganu there were 479 mosques. The mosques in this state were divided into four categories: the state mosque, the district mosque, the main mosque and the government mosque. 


\subsection{Definition of Imam}

The word Imam refer to an individual who was followed by his people there in accordance with the commands of the prophets and the Messenger as specified in Quran: "And We made them leaders by Our command. And We inspired to them the doing of good deeds, establishment of prayer, and giving of zakat, and they were worshippers of Us " (al-Anbiya':73)

Imam is the leader in organizing the mosque activities, particularly in the areas of worship and preaching. The role of the Imam is not just leading the congregational prayers. Moreover, Imams should be able to assist in handling the mosque management, provides religious programs, effective preaching activities for the communities. Hence, Imam with enthusiasm spirit, experienced and profound knowledge, a Imam will be able to meet the responsibilities and expectations assigned to them by society. Imam is a person who is responsible for the leadership which is includes leadership in doing the deeds of worship for the entire earthly life and societal development.

\subsection{Roles and responsibilities of Imam}

Terengganu Religious Affairs Department (JHEAT) has issued a list of duties and responsibilities of the Terengganu Imam which includes ten tasks and responsibilities that must be implemented. This task list is based on the role of the Imam includes: 1 - the official duty, 2 - the administration of the mosque, 3 - self-development and 4- community service. In addition, ten of duties and responsibilities of the mosque imam state government has established:

1. Leading the mosques and monitor the work of officers of the mosque. 2. Leading the congregational prayer during the praying time, Friday Prayer, two 'Eid prayers and tarawih as scheduled. 3. Giving a Friday and the two days Eid sermon which were approved by JHEAT. 4. Delivering a religious lecture for at least three (3) times a week. 5. Planning and organizing activities with the co-operation from the mosque committee members that related to the mosque cleanliness and suitable programs that can be held in the mosque. 6. Building up a systematic administration. 7. Preparing draft for religious lecture, Friday sermons and religious pamphlets. 8. Providing advice and counseling unit. 9. Maintaining good relations and understanding between the mosque staffs, committee members and the community. 10. Accepting and carrying out the instructions of the Commissioner or authorized officer.

\subsection{Position for Imam in the State of Terengganu}

There are about 1180 Imams in Terengganu, includes i) the village Imam level about 1108 Imams, ii) 34 Muballigh Imams and iii) the state mosque imam about 38. Sources from the Terengganu Department of Religious Affairs JHEAT, 15/8/1996 stated that the government has approved Imams position according to the grades S41 for 9 Imams, 10 Imams for S27 and 42 Imams for S17 but the appointment is yet to be implemented. Furthermore, the applications for the appointment of Imams was approved on $6{ }^{\text {th }}$ February 2007 which indicated that the state mosque has been given one position for the schemes of grade S48, S41, S32 and S22 while one position for grade S41 to every district mosque. However, these schemes are yet to be implemented until this research has been conducted.

\subsection{Criteria for selection of Imam}

For the selection of Imam, the most important criteria were the ability of reciting the Quran and have knowledge in Fardhu 'Ain. The researchers being told that in case of any vacant position, an advertisement will be issued by the Department of Islamic Religious Affairs through medias and an interview will be conducted for that purpose (Source: JHEAT).

\subsection{Remuneration and salary for Imam}

There are three parties which are responsible for the salaries of the Imams in this state. The salary is distributed by category of Imams as below:

1). For the Imam Mukim/Village, they will receive an allowance of RM450 which is to be paid by JAKIM and RM200 per month which will be paid by the state government. Overall, they will receive RM650 per month.

2). For the Muballigh Imam (who is appointed by MAIDAM: Council of Religious and Malay Customs of Terengganu): They are usually appointed among the holders of a degree, diploma or certificate of SPM. The degrees holder will be paid lump sum RM800 per month. While diploma holders would be paid RM600 a month and RM500 a month for SPM holder which will be paid by MAIDAM. 
3). For the Imam from Government Mosque, normally they are coming from Government staff that possess Sijil Pelajaran Malaysia and subject to the scheme, contract, temporary and permanent. Till today the maximum grade offered for them is a $\mathrm{S} 17$ grade.

\subsection{Training for Imam}

To maintain the effectiveness of this function, Terengganu Religious Affairs Department (JHEAT) in collaboration with Terengganu Islamic Foundation (YIT) and the Council of Religious and Malay Customs of Terengganu (MAIDAM) regularly provides training courses for imams. For JHEAT, they are planning to build a training centre for the Imam. By so doing, the roles could be maintained and even strengthen this function in future.

\section{Literature Review}

There are few studies on the role of mosques in connection with the role of the Imam, performed by some researchers, such as: a survey conducted by Muhammad Nor Habibi and colleagues (2004), on the perception of the preacher of Friday sermon Kelantan Department of Islamic Religious Affairs (JHEAIK), showing a sermon JHEAIK been recognized by the preacher-khatib as the most appropriate text to be presented to the public. Khatib generally satisfied with the content, the issues discussed, until at the right time and to be appreciated. Similarly, the sermon preacher managed to increase customer satisfaction in the delivery, to increase the piety of congregation and to change their behavior.

There are study of the perception of the mosque congregation for religious lectures at Masjid Sultan Sulaiman, Universiti Teknologi Malaysia, Skudai by Sulaiman Shakib and colleagues (2004). The results of this study could be concluded as follows: i. the whole congregation to give a positive view of organized religion class. ii. The whole congregation showed a positive attitude toward organized religion class iii. The whole congregation to give a negative perception towards the methods and techniques used during religious instructors conduct lectures. iv. The whole congregation to give a positive perception of the role of the mosque as a center for spreading of knowledge.

Nurazmallail, Osman and Zulkifli (2004) also studied the problem of lack response to the program of lectures at the mosque have takmir teachers that need to diversify the teaching and learning methods. The lectures that being conducted should include all social groups and bulletin boards mosque should be constantly updated. According to the theories discussed, it can be concluded that the crucial role of the Imam as a reference point for the community in which they are mediating to disseminate information about the advice and will of religion in society. A study should be conducted to examine the role of a Imam and perform the tasks entrusted to them. The role and performance of the Imam should be seen from the perception of people about their hopes and expectations towards Imam.

\section{Research Instruments}

The questionnaire consists of:

\subsection{A demographic questionnaire for congregations}

This section contains of three questions which are related to the socio-demographic characteristics of the respondents including age, area and level of education by using a closed-ended question which requires the respondent to answer the statement by selecting a specified scale. This method is suitable and conveniently to be asked, it also help in reducing interview bias, faster to set it up, easy to be answered by respondents. This method also provides high input uniformity and ultimately facilitate the data processing business. (Kinnear and Taylor, 1996).

\subsection{A questionnaire on the role and responsibility of Imam mosque}

This section includes questions to collect the particular details of the findings related to the role and responsibility of Imams which involves three main roles as an official duty, community service and the administrator of the mosque. During the interview session, a set of questionnaire forms used to record the information obtained. Form questionnaire for this study is independently developed by researchers with the task of matching the lists issued by JHEAT by using Likert scale ( $1=$ strongly disagree to $5=$ strongly agree). Information from this questionnaire form is analyzed by using the Statistical Package for Social Science (SPSS). Examination of validity (Cronbach coefficient alphas) also has been executed. This questionnaire also has been tested for compliance in a pilot test conducted at Universiti Darul Iman (KUSZA campus). Based on that, overall score reliability coefficient alpha $(\alpha)$ $=.929$. According to Nunnally (1978), the reliability coefficient value of not less than 0.5 is usually acceptable; therefore it is inquired about a used-acceptable reliability coefficient. 


\section{Materials and Method}

The researchers were made a visit to the respondents in September 2007. The study involved a field study which makes an interview with congregations using a convenience sampling. This task is performed by the researchers themselves to ensure only the correct answers were recorded. All districts in the state have been chosen as the location for the collection of data for research purposes. The sample consisted of ten respondents from the regular congregation of the mosque in the state government to make the respondents amounted to 350 people. The reason why the congregation was chosen is very clear, where the views and observations on the movement behavior and leadership of imam mosque where they prayed every day are able to record information that is honest and true.

\section{Statistical Analysis}

\subsection{Data}

The data were processed and analyzed using descriptive statistical package SPSS. A total of 350 questionnaires were processed and only $271(77.4 \%)$ can be used for analysis because the researchers only used the fully answered form whereby there are partially answered form that cannot be analyzed. This part presents the results of studies on the profile of the congregation of the mosque where the study has been conducted, their area, age and their educational level.

\subsection{Profiles of congregation}

Out of the total of 271 questionnaires were analyzed, there were $28 \%$ from Kuala Terengganu, $17.3 \%$ from district of Kemaman, $15.5 \%$ from district of Besut, and the lowest (5.9\%) that come from Setiu district. In terms of age, the majority $(71.2 \%)$ congregation is more than 48 years of age and only $4.4 \%$ of young congregation in the age group under 27 years old. This shows that the congregation of the mosque is the middle class and senior citizens. Pertaining to the educational level obtained by the respondents, the majority of the congregations of the mosque acquired secondary level of schooling which is $84.4 \%$, compared to only $15.6 \%$ those were diplomas and degrees levels.

\section{Descriptive Analysis of the Congregation Perception on the Role of Imam}

\subsection{The role of Imam in society service}

An analysis in this part is concerned about the perception of the congregation of community service performed by the Imam. Perceptions of the congregation in this study refer to the level of their own assessment of community service by a Imam in their place. There are three sections of the society and the role of the Imam, there are 15 statements presented include all three parts. Response scale is divided into five, namely whether Strongly Disagree (SD), Disagree (D), Undecided (U), Agree (A) and Strongly Agree (SA).

\subsection{Cooperation in organizing activities / programs}

In this item, the researchers would like to examine the first mosque imam role of the community service that a collaboration in organizing activities and programs of the mosque. The first part that mosque imams and committee members have a good working relationship, $57.2 \%$ of respondents said that agreeing and $31.7 \%$ were expressed strongly agree. Only $0.7 \%$ of respondents strongly agree that there is a good relationship between Imam and the committee members in organizing programs. Thus, the researchers concluded that the high percentage of agree indicates that the relationship between the Imam and the mosque committee members are in a good condition.

For the second item attempted to find the issue of Imams attendance towards all programs and activities organized within the society. The result shows that $58.7 \%$ of respondents agreeing and $24.4 \%$ were expressed strongly agree. Percentage of agree indicates that the imam regularly attended each program or activity. Item three discovered the smooth running of the program that been conducted which no respondents strongly agree with the above issues. Once again the percentage of agree and strongly agree with the highest percentage of $87.8 \%$. Based on the above result, it proves that every programs and activities conducted by the Imam are running smoothly.

While the fourth item determined the issues of the program planning that run by the imams and committee members which indicated that $53.9 \%$ of respondents stated agree, $28.4 \%$ strongly agree, $14 \%$ are not sure, $3.7 \%$ disagreed, and no disagreement answer have been recorded. Form this scenario, the researchers concluded that high percentage of agree shows that the imam and mosque committee members succeed in planning programs.

The fifth item sought to examine whether Imams get good cooperation from all sides for each activity or program that have been planned. From the analysis, it is clearly indicated that $60.1 \%$ of respondents stated agree, $23.6 \%$ strongly agree, $12.5 \%$ uncertain, $3.3 \%$ disagreed and $0.4 \%$ answered strongly disagree. A high percentage of agree indicates that the Imam received full cooperation from all sides for each activity or program. The last item 
requested the respondents to verify whether every mosque committee members played their respective roles in the successful of the program. The results revealed that $40.8 \%$ of respondents stated agree, $24.7 \%$ strongly agree, $20.3 \%$ uncertain, $6.6 \%$ disagreed and $0.4 \%$ answered strongly disagree.

\subsection{Imam provide advisory/ counseling services for community}

The first item wanted to examine whether the Imam led the discussion of issues related to the community. The results showed $39.5 \%$ out of respondents said that they identified and agreed, while $11.1 \%$ also said they agree and $5.9 \%$ strongly agree. Only $4.1 \%$ of respondents strongly disagreed the Imam led the discussion of issues of life. Equal percentage of agree and certainly did not, it can be assumed that some respondents did not know the duties of a Imam is leading discussion of life issues for the community.

For the second item attempted to find the issue of Imams provide a schedule for advisory services at the mosque. Nearly $41.7 \%$ of respondents agreed and $5.2 \%$ of respondents expressed strongly agree. While $32.5 \%$ are uncertain, $15.9 \%$ disagreed and $4.8 \%$ strongly agree. Once again, the same percentage of agree and not sure, would showed that most of the respondents did not know the duties of a Imam is to provide a schedule for advisory services at the mosque.

The third item is to find out whether the Imam becomes a place for people come to them for counseling needs. The analysis reported that $34.7 \%$ of respondents uncertain it is the role of imams, nearly $49.1 \%$ agree and $16.6 \%$ of respondents did not agree. This percentage shows us that respondents are not recognized Imam as a place for counseling needs.

The last item aim to find out whether the Imam becomes a head of advisory services and counseling within the community, the results showed that $34.3 \%$ of respondents agreed, $14.8 \%$ were strongly agree, $13.3 \%$ of respondents did not agree and $3.3 \%$ out of the total respondents strongly disagreed.

\subsection{Good relations between Imam and committee member}

The last role for the community service is a good relationship with the committee and a member of the community. The first item is to examine whether the members of the society attended the wedding ceremony which comes from Imams. The results revealed that $52.4 \%$ of respondents agreed and $19.6 \%$ were expressed strongly agree, $22.1 \%$ of respondents are not sure and $5.9 \%$ of respondents strongly agreed. The high percentage of agree indicated that the committee members attended the ceremony invited by the Imams. For the second item touched the issue whether the Imams attended the ceremony that been invited by the committee members. It can be observed that $51.7 \%$ of respondents agreed and $22.9 \%$ were expressed strongly agree. Generally, one can conclude that the Imams have attended the ceremonies organized by the community.

The third item is to find out whether Imam and committee members always say hello. The results revealed that no respondents strongly disagree with the above issues. Once again, the percentage of agree and strongly agree with the highest percentage of $90.8 \%$, it showed that Imam and committee always say hello.

The fourth item is to verify whether there is an event of visiting each other between Imams and members of the society, the analysis found no respondents who strongly disagree with the above issues. Once again, the percentage of agree and strongly agree with the highest percentage of $88.9 \%$ showed that they are communicated and visited each other. With the last item, the aim was to find out whether the community visiting the Imam and the mosque committee members. The results indicated that $52 \%$ of the respondents agreed, $27.3 \%$ strongly agree, $15.9 \%$ uncertain, $4.4 \%$ disagreed and $0.4 \%$ of respondents answered strongly disagree. It can be observed that a high percentage agreed between the Imam and committee members showed they are regularly visit each others.

\subsection{Congregations perceptions on Imam official duties}

Perceptions of the congregation in this study refers to the extent that their own observation of the official duties of Imam in their places. There are four sections of the society and the role of the Imam, there are 19 statements presented include all four parts. Response scale is divided into five, namely whether Strongly Disagree (SD), Disagree (D), Undecided (U), Agree (A) and Strongly Agree (SA).

7.5.1 Official duties of Imam is to lead the prayer

For the first role of the Imam of the official duties of the Imam is to lead the prayer. The first item is to verify whether the Imam leading the Friday prayer. The majority (91.5\%) of the respondents stated that $31.7 \%$ agreed and also expressed strongly agree. Only $0.7 \%$ of respondents strongly agreed Imams in their place to lead the Friday prayers.

The second item is designed to ask the respondents whether the Imam is leading the Eid prayer. This resulted that $48.3 \%$ of respondents agreed and $31.4 \%$ were expressed strongly agree. The high percentage of agree indicated 
that the Imam led the prayers at their feast. The third item is to examine the quality of Imams recitation of al-Quran is good. The results revealed that $41.7 \%$ of respondents agreed, $18.8 \%$ strongly agree, $27.3 \%$ are uncertain, $10.3 \%$ disagreed and $1.8 \%$ of the respondents did not agree. It is observable that the high percentage of agree indicates that reading standards are good in the view of the congregation of the mosque.

The fourth, fifth, eighth and ninth of the items are on the issue of schedules are available for the task of the Imam who leads prayers, readings are adjusted according to verses in the prayer time, reading wirid adjusted according to the time, Imam attended to the mosque 15-20 minutes before entering prayer time and Imam is always present to mosque, although not on duty, the majority of respondents ( $90 \%$ above) agreed that the Imam has performed an excellent job.

\subsubsection{Imam deliver sermon}

Over $90 \%$ of respondents agreed with the statements about the Imam delivered the Friday sermon, the Imam delivered a sermon two Eids prayer (Idulfitri and Hajj) and the Imam delivered a sermon prepared by JHEAT, except for the statement about Imams delivered sermons on the issue of prepared by themselves. In contrast, the majority of respondents either did not identify and did not agree to the Imam delivered a sermon that made by his own.

\subsubsection{Imam delivering a religious lecture}

The first statement is Imam prepared a schedule for delivering religious lectures, $47.2 \%$ of respondents stated agree, $27.7 \%$ strongly agree, $15.5 \%$ uncertain, $6.3 \%$ disagreed and $3.3 \%$ answered strongly disagree. High percentage of agree indicates that the Imams prepared a schedule for delivering religious lectures.

\subsubsection{Accept commissioner instructions and commands}

The first item sought the views of respondents on Imam has receive and understand the commissioners instructions and commands, Specifically, with $48.3 \%$ of respondents stated agree, $36.2 \%$ strongly agree, $14.8 \%$ are uncertain, and $0.4 \%$ respectively disagree while $0.4 \%$ of respondents are strongly disagree. Higher percentages of agree indicated that the respondents knew that among the Imam duties is also to receive and understand the commissioner instructions and commands.

\section{Results}

\subsection{Imam as a mosque manager}

Perceptions of the congregation in this study refer to the level of their own observations towards Imam as a mosque administrator in their place. There are two sections of the Imams role for the society, there were 13 items presented including this two parts. Response scale is divided into five, namely whether Strongly Disagree (SD), Disagree (D), Undecided (U), Agree (A) and Strongly Agree (SA).

\subsubsection{To create a systematic mosque administration}

For the first role of the Imam as an administrator of the mosque is how to create a tidy and systematic mosque administration. A high percentage of agree to all the facts and issues raised under this role shows that Imam as an administrator has succeeded in creating a successful and systematic administration.

\subsubsection{Leading the mosque activities and monitoring the staff}

Imam as a head of the mosque staff, and monitoring the other staffs job, showing a high percentage of agreeing to the item number one, two, three and five. There are two item that show the uncertainty of the respondents to the duties of Imams either mosque officials understand the given task and whether the Imam had ICT skills.

\section{Discussion}

According to the research finding one could say that the respondents gave a positive perception of the role of the Imam towards community services. This leads to that the Imams understand the duties and functions assigned to them. They are not just to lead the congregational prayer in a mosque but even join the community in social activities.

Totally, the respondents gave a positive perception of official duties as a Imam who was appointed special officials to head the congregation in prayer and carrying out the delivery of sermons and giving a religious lectures. The respondents gave a positive perception of the role of the mosque imam as an administrator, supervised officers under them and carried out the task entrusted to him as the manager of this institution.

Also, the respondents are generally aware of what the roles and responsibilities of Imam who is appointed. This simplifies the implementation of programs compiled by the authorities. 


\section{Conclusion}

The researchers have conducted interviews with various parties concerned, including the Imams themselves. The study had some useful information to be used by the authorities, especially in making some improvements in management and administrative institutions which are closely related to JHEAT, among them are:

\subsection{The Ordination of salary}

This study recorded that there are three parties charged with the responsibility to pay the salaries and allowances to the Imams in Terengganu. They are the state government through the Secretary of the state office, The Council of Islamic Religion and Malay Customs (MAIDAM) and Department of Islamic Development Malaysia (JAKIM). These wage rates and allowances will vary depending on the ability of those bodies to pay. Hence, the researchers would like to propose that the payment should be coordinated.

\subsection{Standard Employment Scheme}

The government should upgrade the Imams employment scheme from SPM grade scheme to graduation scheme. Throughout this study, the researchers found that currently practiced by the state, Imam who has a degree was granted by MAIDAM lump sum allowance of RM 800 per month. For instance, this group does not facilitate by the government as a public servant. Therefore, the researchers suggested that the government should urgently implementing an application for appointment of a Imam which has appointed on 6-2-2007, one imam to be appointed under schemes grades S48, S41, S32 and S22 respectively, and one Imam under scheme S41 for each district.

\subsection{Providing Training Institute for Imam}

We proposed that the state Government might expedite in establishing a training institutes for Imams. The Government could provide experts who are capable to train these Imams as well as training modules should be sought. The government may seek the cooperation with the Faculty of Islamic Contemporary Studies University Sultan Zainal Abidin which have so many expertise in this field.

\section{References}

Abdurrahman Raden Aji Haqqi Dr. (2004). The Contemporary Roles of the Mosque: An Assessment Related to Its Leadership Platform. Inside Institutional Mosque Seminar. Brunei Darul Salam: Department of the Prime Minister.

Ahmad Shukri Assoc Prof Dr., \& Muhammad Rafie Hj Khadafi. (2004). To Socialization of the mosque. Inside National Mosque Management Seminar. Sintok: Islamic Center of UUM.

Al-Zuhayli, Wahbah. (1991). Al-Fiqh al-Islami wa Adillatuh. Bayrut: Dar al-Fikr.

Department of Religious Affairs Terengganu. The Action Plan To Make Mosque as The Institute of Islamic Culture and The Creator for the Community.

Department of State Religious Affairs. list of duties and responsibilities of Islamic Affairs Assistant (Imam) Masjid-Masjid Darul Iman Terengganu State Government.

Mohd Murtadza bin Hj Ahmad YBSS Dato 'Haji. (2006). Role of Imams in the mosque. Inside Professionalism Enhancement Course for Imam and Bilal in Seremban Mosques.

Mohd. Mokhtar Bin Shafi'i Dato’ Hj. (2003). Status of Imam in Malaysia. Inside Building Mosque Institution. Kuala Lumpur: Department of Da'wah and Human Development, the Academy of Islamic Studies, Universiti Malaya.

Sulaiman bin Ibrahim Al-Baruhi Dr. (2006). Imam According to the Sunnah of the Prophet. Inside Professionalism Enhancement Course Imam and Bilal in Seremban Mosques. 